Karatay, H. ve Aksu, Ö. (2017). 4+1 planlı yazma ve değerlendirme modelinin 8. sınıf öğrencilerinin ev ödevlerini hazırlamaya etkisi. Ana Dili Eğitimi Dergisi, 5(2), 313-335.

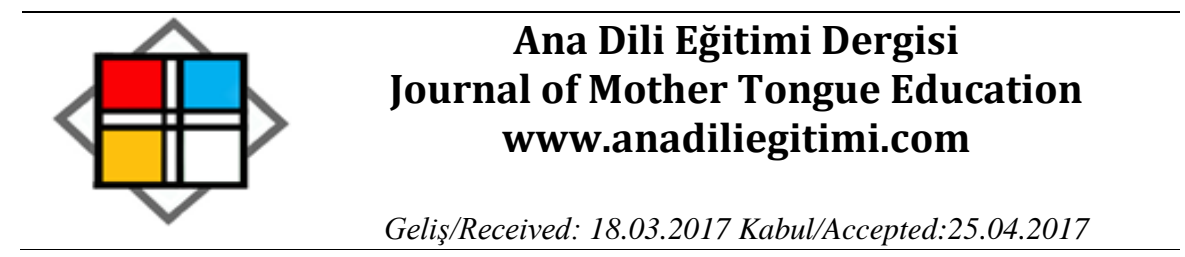

\title{
4+1 Planlı Yazma ve Değerlendirme Modeli’nin 8. Sınıf Öğrencilerinin Ev Ödevlerini Hazırlamaya Etkisi
}

\begin{abstract}
Halit KARATAY
Özlem AKSU²

Öz

Bu çalışmada, süreç temelli yazma modellerinden biri olan 4+1 Planlı Yazma ve Değerlendirme Modeli'nin ortaokul 8. sınıf öğrencilerinin performans görevlerini yapmaya etkisi incelenmiştir. Araştırmada ön-son test kontrol gruplu deneysel modelin yanında nitel araştırma yöntemlerinden görüşme kullanılmıştır. Araştırmanın örneklemini Ankara'da bulunan HBV Ortaokulunda öğrenim gören 164 8. sınıf öğrencisi oluşturmuştur. Araştırmada deney grubu öğrencilerinin yazma çalışmaları 4+1 PYDM'ye göre haftada iki saat olarak düzenlenmiş, kontrol grubu öğrencilerine ise Türkçe derslerinde geleneksel yazma çalışmaları yapılmıştır. 4+1 PYDM uygulama etkinlikleri 12 hafta sürmüştür. Araştırmada veri elde etmek için 4+1 PYDM Değerlendirme Ölçeği ile Yazılı Anlatım Tutum Ölçeğinin yanı sıra araştırmanın nitel bölümünde kullanılan tek soruluk görüşme formu kullanılmışıı. Araştırma sonucunda; deney grubu öğrencilerinin ön test-son test planlı yazma becerileri arasında anlamlı bir farkın olduğu belirlenmiştir. Deney ve kontrol grubu öğrencilerinin son test planlı yazma becerileri arasında anlamlı bir farkın olmadığı ancak yazma sürecinin planlama aşamasına ilişkin deney grubunun lehine anlamlı bir farkın olduğu belirlenmiştir. Kontrol grubu öğrencilerinin ön test-son test planlı yazma becerileri arasında anlamlı bir farkın olmadığı belirlenmiştir. Deney ve kontrol grubu öğrencilerinin ön test-son test yazııı anlatım tutumları arasında anlamlı bir farkın olmadığı belirlenmiştir. Deney grubu öğrencilerinin 4+1 PYDM uygulamaları sonunda gerçekleştirilen bu yazma modeli ve yazıı anlatım ile ilgili görüşmeye göre; $\% 76,8^{\prime}$ inin çalışmayı kendisi için faydalı bulduğu, $\% 12,1^{\prime}$ inin çalışmayı kendisi için faydalı bulmadığı ve $\% 10,9^{\prime}$ unun kararsız kaldığı tespit edilmiştir.
\end{abstract}

Anahtar Kelimeler: 4+1 Planlı Yazma ve Değerlendirme Modeli, 8. sınıf öğrencileri, yazma tutumu, yazılı anlatım.

\section{Impact of 4+1 Planned Writing and Evaluation Model on Homework Preperation of $8^{\text {th }}$ Grade Students}

\begin{abstract}
In this study, impact of the 4+1 Planned Writing and Evaluation Model, which is one of the process based writing models, on $8^{\text {th }}$ class student's way of making their performance works was assessed. In the research, in addition to the pretest-posttest control group design, interview is used as a qualitative research method. Sample of the research is $1648^{\text {th }}$ class students from HBV Secondary School located in Ankara. Lectures of the experimental group were arranged as 2 hours per week in accordance with the 4+1 PWEM, whereas writing studies of the control group were designed in line with the general writing expression applications of Turkish lesson. Experimental applications of 4+1 PWEM lasted 12 weeks. In
\end{abstract}

\footnotetext{
${ }^{1}$ Doç.Dr. Abant İzzet Baysal Üniversitesi, Eğitim Fakültesi, halitkaratay@gmail.com

2 Öğretmen, Milli Eğitim Bakanlığı, ozlemtokaksu@mynet.com
} 
the research, the 4+1 PWEM and the Writing Expression Attitude Scales, as well as a single consultation question of the qualitative part of the test were used in order to obtain data. As a result of the study; it was identified that pretest-posttest planned writing skills of experimental group students have a meaningful difference. It was also identified that there was not a meaningful difference between posttest writing skills of the experimental and the control group students, whereas there was a meaningful difference in favor of the experimental group students regarding to planning stage of the writing process. It was found out that there was not a meaningful difference pretest-posttest planned writing skills of the control group students, there was not a significant difference between pretestposttest written expression attitude scores of the experimental group students, there was not a significant difference between pretest-posttest written expression attitude scores of the control group students. It was determined that there was not a meaningful difference between pretest-posttest written expression attitudes of the experimental and the control group students. From the opinions of the experimental group students on the applied writing model and writing expressions after the completion of the 4+1 PWEM applications, it was observed that $76,8 \%$ of the students found the study helpful for her/himself, $12,1 \%$ of the students did not found the study helpful for her/himself, and $10,9 \%$ of the students stayed indecisive.

Keywords: $4+1$ Planned Writing and Evaluation Model, $8^{\text {th }}$ grade students, writing expression, writing attitudes.

\section{Kuramsal Çerçeve}

Illköğretimin birinci kademesinde verilen yazma eğitiminin amacı, bireyin günlük yaşamında ihtiyaç duyacağı yazma ile ilgili eylemleri gerçekleştirebilecek becerileri kazandırmaktır (Yalçın, 2002). Eğitim sistemimizde bu becerilerin bireye kazandırılması için öncelikle ilk okuma ve yazma eğitimi verilmekte, ardından “cümle, paragraf ve metin düzeyinde (Özbay, 2000)" olmak üzere üç aşama ile yazma eğitimine devam edilmektedir. Cümle, paragraf ve metin aşamalarını art arda ve birbiri ile bağlantılı olacak şekilde öğrenciye kazandırmak amacıyla 2006 İlköğretim 6-8. Sınıf Türkçe Dersi Öğretim Programı ile Türkçe ders kitaplarında "yazma becerisinin geliştirilmesine yönelik" 15 yazılı anlatım yöntem ve tekniğine yer verilmiştir. Bunlar: not alma, özet çıkarma, boşluk doldurma, kelime ve kavram havuzundan seçerek yazma, serbest yazma, kontrollü yazma, güdümlü yazma, yaratıcı yazma, metin tamamlama, tahminde bulunma, bir metni kendi kelimeleriyle yeniden oluşturma, bir metinden hareketle yeni bir metin oluşturma, duyulardan hareketle yazma, grup olarak yazma, eleştirel yazma"dır (MEB, 2006, 7072). Programda öğretmenlerin Türkçe derslerinde bu yöntem ve tekniklerden yararlanmaları ve öğrencilerin yazılı anlatım becerilerini geliştirmeleri önerilmiştir, fakat öğretmenlerin bu teknikleri nasıl uygulayacaklarına dair bilgi ve uygulama örnekleri verilmemiştir. Ayrıca Programda önerilen bu yazma eğitiminin öğrencilerin yazılı anlatım becerilerinin gelişmesinde katkı sağlayacağı vurgulanmıştır. Oysa bu yazma eğitimi anlayışında öğretmenlerin öğrencilerinin yazma sürecinin neresinde eksikliklerinin olduğunu gözlemlemesine yönelik bilgi ve yönlendirme 
yoktur. Bu yüzden öğretmenler, öğrencilerinin yazma sürecini izlemeleri, eksikliklerini ve hatalarını belirleyip yazma becerilerini geliştirmek için neler yapmaları gerektiğinin farkında değildirler. Bu nedenle öğrenciler, yazılı anlatım etkinliklerinde farkında olmadan hep aynı hataları yapabilmekte, yazılı anlatım sürecinin işleyişi ve nitelikli yazı ortaya koymak için neler yapılması gerektiği hakkında bilinçli eylemlerde bulunamamaktadırlar. Geleneksel anlayışla yürütülen yazııı anlatım çalışmaları bilinçli bir yazma eğitimi sürecinden yoksun olduğu için de öğrencilerde yazılı anlatımın iyi bir beceri olarak geliştirilmesi mümkün olamamaktadır. Dahası öğrenciler yazma sürecinde yaptıkları hatalarının farkına varmadan onları aynen tekrar ederek kalıcı ve yanlış öğrenmelere de neden olabilmektedir.

Yazma becerisinin gelişimi, diğer dil becerilerine göre daha çok uygulama çalışmaları gerektirdiği için yavaştır ve zaman alır. Cumhuriyetin ilk yıllarından bugüne kadar öğretim programlarına bağlı olarak okullarda yapılan yazma eğitimi çalışmalarının temel ve nihai amacı, “öğrencilerin herhangi bir konuda duygu, düşünce, hayal ve izlenimlerini anlatabilme" becerisi edindirmektir. Bunun yolu ise öğrencilerin yazılı anlatım sürecini bilinçli eylemlerle ve kendi kendilerine yürütebilme bilinci ve alışkanlığı olan özdenetim kazandırmaktır. Bunu gerçekleştirmek için yazma eğitimi çalışmalarında öğrencilere konu ve ürün odaklı geleneksel yazma eğitimi anlayışından çok, yazmada belli aşamalar izlemek ve 3-5 yazılı anlatım çalışmasında öğrencilerle sesli düşünme tekniği kullanarak ne ve nasıl yaptıkları hakkında her aşamada onlara bilinç kazandırmak gerekir (Karatay, 2011a-b; Özdemir, 2014). Geleneksel yazma eğitimi çalışmalarında süreci işletmeyi öğretmek yerine ürün yani ortaya çıkan yazılı anlatım metni değerlendirilmektedir. Fakat yazılı anlatım sonunda ortaya konan ürünün yeterliliğini değerlendirmekle öğretmen, öğrencinin metni oluşturma sürecinde yaptığı yanlışların ve yazma sürecinde izlediği yolda nasıl ilerlediğinin farkına varamamaktadır. Yazmanın en başından sonuna kadar öğrencinin konu belirleme, sınırlandırma, konuyu nasıl ele alacağını tasarlama ve yazıya aktarma, geliştirme ve düzeltme aşamaları hakkında bilinç edinmesi mümkün olamamaktadır. Dahası öğretmenler de yazma eğitimi derslerinde yazılı anlatım sürecini öğrencilerle belli ilkeleri izleyerek nasıl yürüteceklerini bilmemektedirler.

Okullarda yıllarca uygulanan ürün odaklı geleneksel yazma eğitiminde öğretmenler, öğrencilerin yazma sürecini izlemedikleri için metnin son halini değerlendirmeye odaklanırlar. Çünkü kalabalık sınıflarda "yazının içeriğinden çok dış görünüşünü değerlendirmek daha kolay olduğundan, yazılı anlatım sürecini izleme ve değerlendirme etkinliklerine yer verilmez" (Karatay, 2011a, 22). Bu anlayış ise yıllardır öğrencilerin hem yazma süreci hakkında bilinçlenmelerini engellemiş hem de nitelikli bir yazıda bulunması gereken özellikleri 
öğretememiş, yazma becerilerini geliştirememiştir. Dahası kompozisyon adı altında okullarda yapılan bu tür uygulamalar, öğrencilerin Türkçe derslerine ve yazılı anlatıma karşı olumsuz tutum geliştirmelerine neden olmuştur.

\section{Süreç Odaklı Yazma Eğitimi}

Süreç temelli yazma yaklaşımı, yazılı anlatım çalışmalarının sonunda yazıda bulunması gereken dil ve anlatım özellikleri, yazım ve noktalama kurallarını uygulama becerilerini metinde gösterme açısından değil; yazma sürecini planlama, geliştirme ve düzeltme, yani yazma sürecini kendi kendine yürütme, özdüzenleme becerileri edinme açısından ele alır. Bu yaklaşım, yapılandırmacı öğrenme kuramı anlayışına göre önceden aşamalandırılmış yazma sürecini öğretmenlerin bilişsel desteği ile düzenlemeyi hedeflemektedir. Süreç içinde öğretim “öğrencilerin düşünme sürecinde yoğunlaşmalarını, bilgiyi aktarmalarını, genel olarak süreci düzenlemelerini ve her aşamaya ilişkin bilişsel farkındalık sahibi olmalarını -kısaca öğrenme sürecinde etkin olmalarını- önerir" (Karatay, 2011a: 25). Öğrencilere yazılı anlatım becerileri edindirmek için ürünü veya yazma sürecini önceleyen farklı yazma modelleri sunulmuştur. Genel eğilim, ürün temelli yazma yaklaşımları yerine süreç temelli yazma yaklaşımlarının ön planda olması gerektiği yönündedir. Alan uzmanları bunun için de sürece dayalı yazma eğitimi çalışmalarının yürütülebileceği çeşitli modeller sunar. Süreç temelli yaklaşımda yazma süreci çeşitli aşamalara ayrılarak aynı amaca yönelik önceliği ve sayısı farklı başlıklar altında görülmektedir (Kaldırım, 2014 ve Özkara, 2006; Karatay, 2011a). Bu aşamalar, modellerin geliştirildikleri yıllara, uygulandıkları bölge şartlarına, okur veya yazar açısından bir metinde bulunması gereken ölçütlere, değerlendirme anlayışları ve geliştirilen ölçme araçlarına göre farklılaşmaktadır. Fakat yazma sürecinin aşamaları arttıkça süreç karmaşıklaştığı için öğrencilerin yazdıkları konuya karşı dikkat ve ilgileri dağılabilir. Öğrenci sayısının fazla olduğu sınıflarda öğretmenlerin bu süreçleri izlemeleri, değerlendirmeleri ve öğrencilerine dönütler vermeleri güçleşebilir (Karatay, 2011b: 1034). Çeşitli araştırmacıların farklı yıllarda üzerinde durduğu süreç temelli yazmanın genel olarak şu temel aşamalardan oluştuğu söylenebilir (Akyol, 2012; Coşkun, 2007; Culham, 2010; Flover ve Hayes, 1977; Johnson, 2008; Karatay, 2011a; MEB, 2012; Tompkins, 2005; Tompkins, 2008):

1. Yazma öncesi hazırlık,

2. Yazma taslağı oluşturma, planlama ve yazma denemesi,

3. Yazma taslağını gözden geçirme, geliştirme,

4. Yazma taslağını dil ve anlatım yönünden düzeltme, 
5. Yazıyı paylaşma, yayınlama, yani sunum.

Bu aşamaları Karatay (2011b), 4+1 Planlı Yazma ve Değerlendirme Modeli şeklinde sunmuştur. Bu çalışmada, bu modelin öğrencilerin yazma becerileri üzerindeki etkililiği üzerinde durulmuştur.

\section{4+1 Planlı Yazma ve Değerlendirme Modeli}

Yazmayı süreç açısından ele alan modellerden 4+1 Planlı Yazma ve Değerlendirme Modelinde öğretmen, yazma sürecinin başından sonuna kadar öğrenci ile iş birliği içindedir. Öğretmen öğrencinin yazma sürecini bilinçli olarak yürütmesi için yol gösterici, rehber niteliğindedir. Yazma sürecinin aşamalarında ortaya çıkan ürün ile ilgili öğrenciye dönüt vererek yazısını tekrar gözden geçirmesini, eksiklerini görerek geliştirmesini sağlar.

Bu aşamalar birbirini takip etmekle beraber bir önceki aşama bir sonrakinin temelini de oluşturmaktadır. Aşamalar arasında geçişler ileriye doğru olabildiği gibi geriye doğru da olabilmektedir; gerektiğinde önceki aşamalara da dönülebilir. Toplam beş aşamada gerçekleştirilen yazma eğitimi sürecinde aşama sayısının hem nitelikli ürün özelliklerini hem de yazma sürecinde izlenmesi gereken temel aşamaları da içermesi bakımından yeterli olduğu düşünülmektedir. Yazma sürecinin aşamaları incelendiğinde modelin hem nitelikli yazma ürünü hem de yazma süreci ile ilgili aşamaları kapsayan kolay yönetilebilir bir model olduğu söylenebilir. Buna göre yazma süreci aşamaları şu şekilde modellenmiştir:

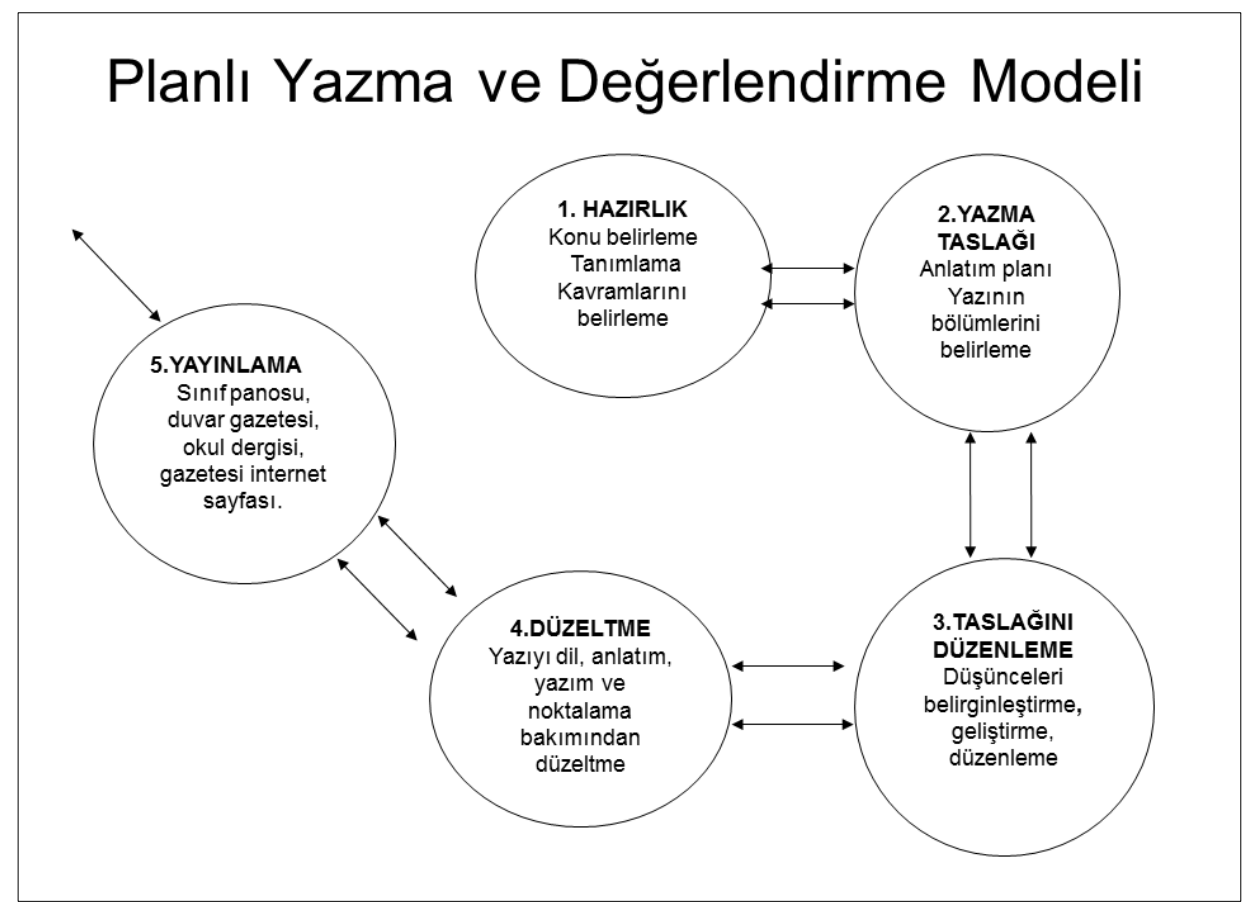

Şekil: 1. 4+1 Planlı Yazma ve Değerlendirme Modeli (Karatay, 2011a: 30). 
4+1 Planlı Yazma ve Değerlendirme Modeli'nin aşamaları.

1. Hazırlık aşaması: Bu aşamada ilk önce yazma konusu belirlenir, bununla ilgili beyin fırtınası yapılır ve öğrencilerin konuyla ilgili neler bildiği ortaya konur. Konuyla ilgili anahtar kelimeler belirlendikten sonra gerekirse bilgi teknolojilerini kullanarak konuyla ilgili araştırma yapmalarına süre de verilir. Konunun ana ve alt kavramlarını belirleme çalışmaları yapılır, öğrencilerin konuyla ilgili yeteri kadar bilgi sahibi olmaları sağlanır. İkinci aşamada öğrencilerin kendilerine konuyla ilgili bir yazma amacı, türü, yazının uzunluğunu ve hedef kitlesi olan okuyucuları belirlemeleri, yani konuyu sınırlandırmaları istenir. Böylece onların yazma konusu üzerinde daha etkili düşünmeleri sağlanmış olur. Hazırlık kısmı yazmaya başlamadan önce konu belirleme, fikir üretme; yazma amacı ve türü belirleme gibi alt aşamalardan oluşmaktadır.

2. Planlama ve yazma taslağı oluşturma aşaması: Bu aşamada eldeki bilgilerin, konuyla ilgili belirlenen ana ve alt kavramların yazıda nasıl sunulacağına karar verilir, yazma çalışması için anlatım planı oluşturulur. Yani yazının giriş, gelişme ve sonuç bölümleri, yazının ana ve alt bölümlerine karar verilir. Yazılı anlatım etkinlikleri öncesinde yapılan hazırlıkta konu belirleme, fikir üretme; yazma amacı ve türüne karar verme, öğrencilerin iyi ve anlaşılır bir yazı oluşturmaları için yeterli değildir. Bunun için yazıda söyleneceklerin planlı bir anlatım akışı içinde sıralanması, anlamca ilgili olan kavramların sınıflandırılması, metnin hangi bölümünde nelere yer verileceğinin belirlenmesi, özetle metnin anlatım planının çıkarılması ve ardından bunun yazılı anlatıma geçirilmesi gerekir.

Yazılı anlatım öncesinde anlatım planı yapmak yazma sürecini hızlandırır, karasızlığa düşüp yazarken zaman kaybına uğrama, konu dışına çıkma, gereksiz ayrıntılara girme gibi sorunların önüne geçer. Yazının daha tutarlı ve anlaşılır olmasını sağlar (Beyreli, Çetindağ ve Celepoğlu, 2011: 45; Emir, 1986: 71; Kaldırım, 2014; Karatay, 2011a; Pilav ve Ünalan, 2012: 34). Bu aşamada, öğrencilerin hazırlıkta yaptığı çalışmalar sonucunda belirledikleri anahtar sözcükleri, ana ve alt kavramları konu ve yazma amaçları olan ana düşünceyi dikkate alarak bir yazılı anlatım planı oluşturmaları sağlanır. Öğrencilerden, yazılarının bölümlerine ve alt başlıklarına, ana düşünceyi destekleyen yardımcı düşüncelere karar vermeleri ve bunları nerede işleyeceklerinin taslağını 
oluşturmaları istenir. Bu aşamada yazılı anlatım için belirlenen metnin türüne göre öğrencilerin bilgilendirici ve tartışmacı anlatım türleri için sınıflama veya balık kılçığı; öyküleyici anlatım türü için olay zinciri gibi kavram haritalarından yararlanmaları sağlanır. Kavram haritaları, yazılı anlatım için yazma planı oluşturmada zorlanan öğrenciler için kolaylık sağlar.

Yazılı anlatım deneyimi yönünden zayıf olan öğrenciler için öğretmen, ilk birkaç uygulamada sınıfta örnek yazma planı getirip göstermeli, daha sonra öğrencilerle birlikte yazılı anlatım planı oluşturmalıdır. Birkaç uygulamadan sonra öğretmen öğrencilerin kendi kendilerine anlatım planı oluşturmalarına fırsat vermeli, oluşturdukları anlatım planı hakkında onlarla görüşmeli, bu görüşmelerde onlara planları hakkında sorular sorarak anlatım planını nasıl yaptıkları hakkında bilinç edinmelerini sağlamalıdır.

Yazılı anlatım planı oluşturulduktan sonra öğrencilerin konuyla ilgili duygu ve düşüncelerini yazmaları için onlara yeteri kadar yazma zamanı verilir. Bu çalışmadan sonra yazının ilk taslağı hazırlanmış olur.

3. Yazma taslağını gözden geçirme, düzenleme ve geliştirme aşaması: Yazılı anlatım planının yazıya geçirilmesinin ardından öğrencilerin yazılarını okumaları, anlatmak istediklerini gözden geçirerek yazılarında vermek istedikleri duygu ve düşünceyi değerlendirmeleri; düzenleme ve geliştirmeleri istenir. Yazıda duygu ve düşünce yönünden yetersiz ve anlaşılmayan bölümlerin geliştirilmesi; konu, ana düşünce ve duyguyu doğrudan desteklemeyen gereksiz ayrıntıların yazıdan atılması ve yazıda yeniden düzenleme ve geliştirme yapılması sağlanır. Bu aşamada yazının içerik yönünden okuyucuyu tatmin edici niteliğe kavuşması için nelerin yapılması gerektiği üzerinde düşünülür. Bu, 4+1 PYDM'yi ürün odaklı yazma yaklaşımlarından ayıran en önemli aşamasıdır. Öğrencilere yazının niteliği ile ilgili verilen dönüt ve değerlendirmeyi içerir. Bu sayede onların "düşüncelerini belirginleştirme, geliştirme ve yeniden düzenlemeleri” için olanak sağlanır. Öğrencilerin yazma sürecini bitirip metni sunmadan önce anlatımda yaptıkları hataları görmeleri, eksiklerinin farkına vararak bunları tamamlamaları sağlanır.

Yazma taslağını gözden geçirme ve geliştirmede amaç, öğrencilerin kendi yazdıklarını incelemeleri ve eleştirel bakış açısıyla değerlendirme becerileri edinmelerini 
sağlamaktır. Bunun için planlama aşamasında olduğu gibi öğretmen-öğrenci, grupöğrenci ve akran değerlendirme tekniklerinden birinden yararlanılarak öğrencilere yazılarının niteliği hakkında dönütler verilir. Öğrencilerin öz değerlendirme becerisi edinmelerini sağlamak için de bu aşamada onların kendi kendilerine "Bu yazıyı daha iyi nasıl yazabilirim? Bu yazı anlaşılır mı? Bu yazının bir gelişme, sonuç bölümü var mı? Konuyla ilgili olarak farklı nelere yer verebilirim? Yazımı desteklemek için kullandığım ifadeler yerli yerinde kullanılmış mı? Konuyla ilgili arkadaş(lar)ımla ve öğretmenle yaptı̆̆ım görüşmeler beklentimi karşılıyor mu?" vb. soruları sormaları istenebilir (Karatay, 2011a: 36). Öğretmen bu sorulardan amaca uygun olan birini veya birkaçını tahtaya yazarak öğrencilerin bunları dikkate alarak yazılarını geliştirmelerini isteyebilir.

Öğrencilerin, okuma ve gözden geçirmede aldıkları dönütler doğrultusunda yazılarını yeniden düzenlemeleri, geliştirmeleri için onlara tekrar yeteri kadar yazma zamanı verilir.

4. Yazıyı düzeltme aşaması: Bu aşamada öğrencilerin yazılı anlatım ürünleri, "dil ve anlatım; yazım ve noktalama" olmak üzere iki yönden değerlendirilir. Yazılar dil ve anlatım yönünden değerlendirilirken "cümle akıcılığı, anlatım bozukluğu ve bağlama uygun kelime seçimi" gibi anlatım özelliklerinin uygunluğu denetlenir ve uygun olmayan anlatım sorunları düzeltilir. Dil ve anlatım özelliklerini düzeltmenin ardından yazım ve noktalama yönünden düzeltmede ise öğrencilerin yazılı anlatım ürünleri, sözcüklerin, tamlamaların, özel adların yazımı; duygu ve düşünceye uygun noktalama işaretlerinin kullanımı gibi yönlerden incelenir ve düzeltmeler yapılır.

Ürün odaklı yazılı anlatım çalışmalarında öğretmenler tarafından yapılan değerlendirmelerde içerikten çok genellikle yazım ve noktalama ile kâğıt düzeni dikkate alınır. Bu yüzden öğrenciler de yazının içeriğinden çok, görünen dış özellikleri ile ilgilenirler. 4+1 PYDM'de bu aşama, yazılı anlatımın sonunda tutularak önemli olanın yazının dış görünüşü değil, içeriği olduğunun farkına varılması amaçlanır. Geliştirme aşamasından sonra içeriğini tamamlayan öğrenciler, yazılı anlatım metinlerini; nedensonuç, amaç-sonuç ilişkilerinin kullanımı, cümlelerin tutarlılığı, kullanılan cümlelerde anlatım bozukluğunun olup olmadığı, noktalama işaretlerinin doğru kullanılıp 
kullanılmadığı ve yazım yanlışlarının olup olmadığı konularında değerlendirerek anlatacakları açısından yazılarına son şeklini verirler.

\section{Yazıyı ortaya koyma, yayınlama ve sunum aşaması:}

Bu aşamada, "ortaya çıkan yazma ürününün sınıf panosu, duvar gazetesi, okul dergisi, okul gazetesi veya internet sayfasında yayınlanması" için konumlandırılması; kâğıda veya yayımlanacağı ortama kolay okunması için konumlandırılması aşamasından oluşur. Öğrencilerin yazdıklarının sınıf-okul panosunda veya arkadaşlarının görebileceği bir yerde yayınlanması, onları yazılı anlatım çalışmaları için "istekli, özgüvenli ve edebiyata karşı ilgili” yapar (Karatay, 2011a: 38); bu bakımdan önemlidir.

\section{Araştırmanın Amacı}

Okullarda, geçmişten bugüne kadar Türkçe Dersi Öğretim Programlarında belirtilen temel amaçlar ve kazanımlara bağı olarak ürün odaklı yazma eğitimi yapılmıştır. Ürün odaklı geleneksel yazma eğitimi çalışmalarında öğrencilerin metin üretme sürecini izleme, hatalarını değerlendirme ve düzeltme gibi dönütler verilmez. Bu yüzden öğrencilerin, kendi kendilerine nitelikli bir yazılı anlatım ürünü ortaya koyabilmek için izlemeleri gereken aşamalarla ilgili bir stratejileri ve özdenetim becerileri yoktur. Bunun için öğrenciler, yazılı anlatım becerisine dayalı ve bir yazma ürünü ortaya koymayı gerektiren okul ödevleri ile baş etmede yetersiz olabilmekte hatta çoğu zaman bu ödevlerinde büyük katkıyı ebeveynlerin sağladığı bilinmektedir. Bu araştırma, yazılı anlatımın ürün değil, öğretmenin tarafından süreç olarak ele alındığı ve yazmanın değerlendirme-dönüt boyutunu da içinde barındıran “4+1 PYDM"nin, ilköğretim 8. sınıf öğrencilerinin ev ödevlerini yapma becerilerine ve yazılı anlatım tutumlarına etkisini ölçmek amacıyla yapılmıştır. Bunun için araştırmada şu sorulara cevap aranmıştır:

\section{Araştırmanın Problem Cümlesi}

4+1 PYDM'nin 8. sınıf öğrencilerinin ev ödevlerini hazırlama becerilerini geliştirmeye ve yazılı anlatım tutumlarına etkisi var mıdır?

\section{Araştırmanın Alt Problemleri}

1. Deney grubu öğrencilerinin ön-son test yazılı anlatım becerileri arasında anlamlı bir fark var mıdır? 
2. Deney ve kontrol grubu öğrencilerinin son test yazılı anlatım becerileri arasında anlamlı bir fark var mıdır?

3. Kontrol grubu öğrencilerinin ön-son test yazılı anlatım becerileri arasında anlamlı bir fark var mıdır?

4. Deney grubu öğrencilerinin ön-son test yazılı anlatım tutumları arasında anlamlı bir fark var mıdır?

5. Kontrol grubu öğrencilerinin ön-son test yazılı anlatım tutumları arasında anlamlı bir fark var mıdır?

6. Deney ve kontrol grubu öğrencilerinin son test yazılı anlatım tutumları arasında anlamlı bir fark var mıdır?

7. Deney grubu öğrencilerinin 4+1 PYDM ile ilgili görüşleri nelerdir?

\section{Araştırmanın Modeli}

Araştırmanın ilk aşamasında, 4+1 PYDM’nin 8. sınıf öğrencilerinin ev ödevlerini hazırlama becerileri ve yazılı anlatım tutumlarına etkisini belirlemek için "ön-son test kontrol gruplu tam deneysel model" kullanılmış, ikinci aşamada deney gurubu öğrencilerinin süreç temelli yazma çalışmaları ile ilgili izlenimlerini değerlendirmek için de görüşlerine başvurulmuştur. Bunun için uygulama sonunda deney grubu öğrencilerinden uygulamada beğendikleri, beğenmedikleri ve olmasını istedikleri şeyler hakkındaki görüşlerini bir kâğıda yazmaları istenmiştir. Araştırmada hem nicel hem de nitel araştırma teknikleri birlikte kullanılmıştır. Bunun için araştırmanın yöntemi, zenginleştirilmiş karışık desen şeklinde tasarlanmıştır.

Tablo 1. Araştırma deseninin simgesel görünümü

\begin{tabular}{|c|c|c|c|c|}
\hline Gruplar & Seçme Tipi & ÖN TEST & $x$ & SON TEST \\
\hline \multirow{2}{*}{ DG } & \multirow{2}{*}{$\mathrm{R}$} & Y1 & 4+1 Planlı Yazma ve Değerlendirme & Y3 \\
\hline & & $\mathrm{T} 1$ & Modeli Yazma Etkinlikleri & T3 \\
\hline \multirow[b]{2}{*}{ KG } & \multirow[b]{2}{*}{$\mathrm{R}$} & Y2 & & Y4 \\
\hline & & $\mathrm{T} 2$ & & $\begin{array}{l}\text { T4 } \\
\text { T5 }\end{array}$ \\
\hline
\end{tabular}

Yukarıdaki şekilde; DG, deney grubunu; KG, kontrol grubunu; R: deneklerin gruplara yansız atandığını; Y1, T1 ve Y3, T3 deney grubunun; Y2, T2 ve Y4, T4 kontrol grubunun ön ve son test ölçümlerini; $X$ ise deney grubu öğrencilerine uygulanan 4+1 PYDM etkinliklerini göstermektedir. Y1 ve Y2 uygulama öncesinde ön test olarak hem deney hem de kontrol gurubundan istedikleri herhangi bir konu hakkında ev ödevi olarak hazırladıkları yazılı anlatım 
çalışmalarını göstermektedir. T1 ve T2 ise uygulama öncesinde her iki grubun yazılı anlatıma ilişkin tutumlarını belirlemek için ön test olarak uygulanan Yazılı Anlatım Tutumu Ölçeğini ve T5 ise uygulama sonunda deney grubunun 4+1 PYDM hakkında yazılı olarak belirttiği görüşleri göstermektedir. 12 hafta süren 4+1 PYDM etkinlikleri sonunda hem deney hem de kontrol grubunun yazılı anlatımla ilgili tutumlarını belirlemek için Yazıı Anlatım Tutumu Ölçeği (T3-T4) uygulanmıştır. Öğrencilerin yazılı anlatım becerilerinin gelişme düzeylerini belirlemek için de son test olarak (Y3-Y4) yine herhangi bir konu hakkında ev ödevi olarak bir yazılı anlatım çalışması yaptırılmıştır. Deney grubu öğrencilerinin sürece dayalı yazma etkinliklerinin kendilerine sağladığı yararları ve uygulamada karşılaştıkları zorlukları belirlemek için (T5) yazılı olarak görüşleri alınmıştır.

\section{Çalışma Grubu}

Araştırmanın çalışma grubu, Ankara ili HBV Ortaokulu'ndaki 8. sınıf öğrencileridir. Okulun 8. sınıflarında 182 öğrenci vardır. Bu öğrencilerden 18'i öğrenme güçlüğüu, devamsızlık, çalışmaya gönüllü katılmama gibi nedenlerden dolayı araştırmaya katılmamıştır. Bunların dışında kalan 164 öğrencinin bulunduğu toplam 6 sınıftan, yansız atama yoluyla 3'ünün deney, 3'ünün kontrol grubu olmasına karar verilmiştir.

\section{Uygulama Süreci}

Uygulama, deney grubu öğrencilerinin Türkçe dersinde işlenen 3 temaya bağlı hazırlamaları gereken 3 ev ödevini, her ödev için dörder hafta ve haftada 1,5-2 saat izlemek üzere toplam 12 hafta boyunca $(X)$ 4+1 PYDM'ye göre öğretmen rehberliği ile sürdürülmüştür. Kontrol grubunda ise temalara bağlı verilen bu ödevler, geleneksel yazılı anlatım anlayışı ile öğrencilere yaptırılmıştır. Deney grubunda uygulamayı araştırıcılar planlamış ve uygulamış, kontrol grubunda ise farklı bir Türkçe öğretmeni ev ödevlerini yaptırmıştır.

\section{Veri Toplama Araçları ve Teknikleri}

Öğrencilerin ev ödevleri ile ilgili yazııı anlatım çalışmalarını değerlendirmek için Karatay’ın (2013) "4+1 PYDM Ölçeği” kullanılmıştır. Bu ölçekte yazılı anlatım süreci 5 aşamada ve 30 madde; hazırlık (8), planlama (4), geliştirme (8), düzeltme (6) ve sunum (4) ile analitik olarak izlenmektedir. Yazılı anlatım sürecini izlemek için ölçekte yer alan maddeler 1-3-5 (hayır, kısmen ve evet) puanlarıyla değerlendirilmektedir. Öğrencilerden ev ödevi şeklindeki yazılı anlatım çalışmalarını Türkçe dersindeki öğrenme temalarına bağlı olarak hazırlamaları istenmiş̧ir. Her ödevle ilgili yazılı anlatım çalışmasında neler yapacaklarını bilmeleri için 4+1 PYDM Ölçeğinin özdeğerlendirme biçiminde olanı kendilerine verilmiş, öğretmen ise her aşamadan sonra analitik olarak öğrencilerin ölçekteki görevleri gerçekleştirme durumlarını 
izleyerek kendilerine dönüt vermiştir. Böylelikle öğrencilerin aşama aşama ödevlerini hazırlarken nelere dikkat etmeleri gerektiği konusunda daha bilinçli olmaları sağlanmıştır.

Öğrencilerin yazılı anlatıma karşı tutumlarını belirlemek için "Yazılı Anlatım Tutum Ölçeği" kullanılmıştır (Karatay, 2011b). Ölçekte 22 madde vardır. Ölçek, eşit aralıklı ve 1-5 arasında (Kesinlikle katılmıyorum-Tamamen katılıyorum) puanlanan Likert tipindedir. Ölçeğin ön ve son test puanları güvenirlik ortalamalarının Cr. $\alpha$ değerinin .89 olduğu belirlenmiştir. Bu veriler, tutum ölçeğinin yüksek düzeyde güvenilir olduğunu göstermektedir.

4+1 PYDM'nin yararlarını ve uygulamada zorlandıkları durumları belirlemek için deney grubu öğrencilerine gevşek yapılandırılmış mülakat uygulanmıştır. Bunun için "Planlı Yazma ve Değerlendirme çalışması sizin için faydalı oldu mu?" sorusu deney grubundaki tüm öğrencilere sorulmuştur. Öğrencileri etkilememek amacıyla tek tek değil sınıfça uygulanan görüşme için bir ders saati ayrılmıştır. Bütün öğrencilere boş kâğıt dağıtılmış, kâğıda isimlerini yazmadan bu soruyu cevaplandırmaları istenmiştir. Görüşme yaklaşık 20 dakika sürmüştür. Bundan elde edilen verilerin de içerik analizi yapılarak uygulamanın yararları, uygulama sürecinde zorlandıkları durumlar belirlenmeye çalışılmıştır.

\section{Verilerin Analizi}

Verilerin analizinde frekans, yüzde, aritmetik ortalama, standart sapma, ilişkili, ilişkisiz ve tekrarlı ölçümler $\mathrm{t}$ testi, kovaryans (Ancova) ve içerik analizi teknikleri kullanılmıştır.

\section{Deney ve kontrol gruplarının ön test analizleri}

Tablo 2. Deney ve kontrol grubu öğrencilerinin ön test yazılı anlatım becerilerine ait ilişkisiz ölçümler t-testi sonuçları.

\begin{tabular}{|c|c|c|c|c|c|c|c|}
\hline 4+1 PYDM & Grup & $\mathbf{N}$ & $\bar{X}$ & S & Sd & $\mathbf{t}$ & $p$ \\
\hline \multirow{2}{*}{ 1. Hazırlık } & 1. Deney ön test & 82 & 2,35 & 912 & \multirow{2}{*}{162} & \multirow{2}{*}{,- 341} & \multirow{2}{*}{,733 } \\
\hline & 2. Kontrol ön test & 82 & 2,40 & 1,027 & & & \\
\hline \multirow{2}{*}{ 2. Planlama } & 1. Deney ön test & 82 & 2,28 & 1,152 & \multirow{2}{*}{162} & \multirow{2}{*}{ 212 } & \multirow{2}{*}{,832 } \\
\hline & 2. Kontrol ön test & 82 & 2,25 & 1,054 & & & \\
\hline \multirow{2}{*}{ 3. Geliştirme } & 1. Deney ön test & 82 & 2,34 & 961 & \multirow{2}{*}{162} & \multirow{2}{*}{$-2,033$} & \multirow{2}{*}{,044 } \\
\hline & 2. Kontrol ön test & 82 & 2,65 & 978 & & & \\
\hline \multirow{2}{*}{ 4. Düzeltme } & 1. Deney ön test & 82 & 2,68 & , 899 & \multirow{2}{*}{162} & \multirow{2}{*}{$-1,038$} & \multirow{2}{*}{,301 } \\
\hline & 2. Kontrol ön test & 82 & 2,84 & 1,142 & & & \\
\hline \multirow{2}{*}{ 5. Sunum } & 1. Deney ön test & 82 & 2,43 & 1,231 & \multirow{2}{*}{162} & \multirow{2}{*}{,- 869} & \multirow{2}{*}{,386 } \\
\hline & 2. Kontrol ön test & 82 & 2,59 & 1,195 & & & \\
\hline \multirow{2}{*}{$\begin{array}{l}\text { Yazılı Anlatım } \\
\text { Becerileri } \\
\text { Toplam }\end{array}$} & 1. Deney ön test & 82 & 2,42 & ,908 & \multirow[b]{2}{*}{162} & \multirow[b]{2}{*}{,- 893} & \multirow[b]{2}{*}{,373 } \\
\hline & 2. Kontrol ön test & 82 & 2,55 & 967 & & & \\
\hline
\end{tabular}

$* p<.0 .5$ anlamlı 
Tablo 2'de deney ve kontrol grubu öğrencilerinin yazılı anlatım becerileri ön test puan ortalamaları verilmiştir. 4+1 PYDM'ye dayalı yazma eğitimi uygulamaları öncesinde deney grubunun ön test yazılı anlatım becerileri puan ortalamaları $(2,42)$, kontrol grubunun ön test yazılı anlatım becerileri puan ortalamaları $(2,55)^{\prime}$ tir. Deney ve kontrol grubu öğrencilerinin ön test yazılı anlatım becerileri arasında anlamlı bir farkın olup olmadığını belirlemek için puan ortalamaları, ilişkisiz ölçümler t testi ile sınanmıştır. Deney grubu ve kontrol grubu öğrencilerinin ön test yazılı anlatım becerileri arasında anlamlı bir farkın olmadığı $\left[t_{(162)}=-, 893, p>, 373\right]$ belirlenmiştir. Bu veriler, deney ve kontrol grubu öğrencilerinin 4+1 PYDM'ye dayalı yazma eğitimi uygulamaları öncesinde yazılı anlatım becerilerinin - geliştirme aşaması hariç- hazırlık, planlama, düzeltme ve sunum aşamalarında birbirine denk olduğu şeklinde yorumlanabilir.

Tablo 3. Deney ve kontrol grubunun ön test yazılı anlatım tutumlarına ait ilişkisiz ölçümler t-testi sonuçları.

\begin{tabular}{ccccccc}
\hline Grup & $\mathbf{N}$ & $\bar{X}$ & $\mathbf{S}$ & Sd & t & p \\
\hline 1. Deney ön test & 82 & 3,60 &, 611 & 162 &, 093 &, 926 \\
2. Kontrol ön test & 82 & 3,59 &, 496 & & \\
\hline
\end{tabular}

* $\mathrm{p}<0.5$ anlamlı

Tablo 3'te deney ve kontrol grubu öğrencilerinin yazılı anlatıma ilişkin tutumlarının ön test puan ortalamaları verilmiştir. Deney grubu öğrencilerinin yazılı anlatım tutumları ön test puanlarının aritmetik ortalaması $(3,60)$, kontrol grubu öğrencilerinin ise $(3,59)$ 'dur. Deney ve kontrol grubu öğrencilerinin 4+1 PYDM'ye dayalı yazma eğitimi uygulamaları öncesinde yazılı anlatıma karşı tutum ön test puanları arasında anlamlı bir farkın olmadığı $\left[t_{(162)}=, 093, p>, 926\right]$ belirlenmiştir. Bu durumda, 4+1 PYDM'ye dayalı yazma eğitimi uygulamaları öncesinde 8 . sınıf öğrencilerinin yazılı anlatıma karşı tutumlarının hem iyi düzeyde (3,5 puanın üstünde) hem de birbirine yakın olduğu söylenebilir.

\section{Bulgular ve Yorum}

Bu bölümde, 4+1 PYDM'nin uygulandığı deney grubu öğrencilerinin ve geleneksel yazma eğitiminin uygulandığı kontrol grubu öğrencilerinin ilk ve son ödevlerdeki yazma süreçleri ve yazılı anlatım tutumları ile ilgili toplanan verilerin analizlerine yer verilmiştir.

Birinci alt problem: Deney grubu öğrencilerinin ön-son test yazılı anlatım becerileri arasında anlamlı bir fark var mıdır?

Bu problemin çözümlenmesinde, deney grubu öğrencilerinin ön-son test 4+1 PYDM puanı ortalamalarından yararlanılmıştır. Deney grubu öğrencilerinin ön test-son test planlı 
yazma becerileri arasında anlamlı bir farkın olup olmadığını test etmek için "ilişkili ölçümler $\mathrm{t}$ testi" kullanılmıştır. Bununla ilgili veriler Tablo 4'te verilmiştir.

Tablo 4. Deney grubu öğrencilerinin ön-son test yazılı anlatım becerilerine ait ilişkili ölçümler $t$ testi sonuçları.

\begin{tabular}{|c|c|c|c|c|c|c|c|}
\hline Metin türü & Grup & $\mathbf{N}$ & $\bar{X}$ & $\mathbf{S}$ & Sd & $\mathbf{t}$ & p \\
\hline \multirow{2}{*}{ 1. Hazırlık } & 1. Deney ön test & 82 & 2,35 & 912 & \multirow{2}{*}{162} & \multirow{2}{*}{$-1,664$} & \multirow{2}{*}{,098 } \\
\hline & 2. Deney son test & 82 & 2,60 & 1,009 & & & \\
\hline \multirow{2}{*}{ 2. Planlama } & 1. Deney ön test & 82 & 2,28 & 1,152 & \multirow{2}{*}{162} & \multirow{2}{*}{$-2,876$} & \multirow{2}{*}{,005 } \\
\hline & 2. Deney son test & 82 & 2,81 & 1,182 & & & \\
\hline \multirow{2}{*}{ 3. Geliştirme } & 1. Deney ön test & 82 & 2,34 & 961 & \multirow{2}{*}{162} & \multirow{2}{*}{$-2,239$} & \multirow{2}{*}{,027 } \\
\hline & 2. Deney son test & 82 & 2,67 & ,904 & & & \\
\hline \multirow{2}{*}{ 4. Düzeltme } & 1. Deney ön test & 82 & 2,68 & , 899 & \multirow{2}{*}{162} & \multirow{2}{*}{$-2,452$} & \multirow{2}{*}{,015 } \\
\hline & 2. Deney son test & 82 & 3,04 & ,967 & & & \\
\hline \multirow{2}{*}{ 5. Sunum } & 1. Deney ön test & 82 & 2,43 & 1,231 & \multirow{2}{*}{162} & \multirow{2}{*}{$-1,812$} & \multirow{2}{*}{,072 } \\
\hline & 2. Deney son test & 82 & 2,78 & 1,224 & & & \\
\hline \multirow{2}{*}{$\begin{array}{l}\text { Yazılı Anlatım } \\
\text { Becerileri } \\
\text { Toplam }\end{array}$} & 1. Deney ön test & 82 & 2,42 & 908 & \multirow{2}{*}{162} & \multirow{2}{*}{$-2,506$} & \multirow{2}{*}{,013 } \\
\hline & 2. Deney son test & 82 & 2,78 & 936 & & & \\
\hline
\end{tabular}

$* p<.0 .5$ anlamlı

Tablo 4'te deney grubu öğrencilerinin uygulama öncesi ve sonrası yazılı anlatım becerileri puan ortalamaları verilmiştir. Deney grubu öğrencilerinin 4+1 PYDM'ye dayalı yazma eğitimi etkinlikleri uygulamaları öncesi toplam yazılı anlatım becerileri puanı ortalaması $(2,42)$, uygulama sonrası puan ortalaması $(2,78)^{\prime}$ dir. Deney grubu öğrencilerinin ön test ile son test yazıı anlatım becerileri arasında anlamlı bir farkın olup olmadığını belirlemek için puan ortalamaları, ilişkili ölçümler $t$ testi ile sınanmıştır. Deney grubu öğrencilerinin ön-son test toplam yazılı anlatım puanı ortalamaları arasında anlamlı bir farkın olduğu $\left[\mathrm{t}_{(162)}=-2,506, p<.013\right]$ belirlenmiştir. Bu durum, 8. sınıf öğrencilerinin yazılı anlatım becerilerini artırmaya yönelik uygulanan 4+1 PYDM'nin öğrencilerin yazılı anlatım sürecine ait planlama, geliştirme ve düzeltme aşamalarında anlamlı fark yaratacak düzeyde gelişim sağladığını göstermektedir. Bu durum, ilkokul 5. sınıf (Özkara, 2007), 4. sınıf (Sever, 2013), ortaokul 8. sınıf (Şentürk, 2009) ve üniversite 1. sınıf (Karatay, 2011) öğrencileri üzerine yapılan araştırmaların bulguları ile tutarlıdır. 4+1 PYDM ve süreci temel alan benzer yazma modellerinin ürün odaklı yazılı anlatım çalışmalarına göre öğrencilerin yazma becerileri üzerinde olumlu etkisinin olduğu söylenebilir.

İkinci alt problem: Deney ve kontrol grubu öğrencilerinin son test yazılı anlatım becerileri arasında anlamlı bir fark var mıdır? 
Bu problemin çözümlenmesinde, deney ve kontrol grubu öğrencilerinin son test yazılı anlatım becerileri puanlarının ortalamalarından yararlanılmıştır. Deney ve kontrol grubu öğrencilerinin son test yazma becerileri arasında anlamlı bir farkın olup olmadığını test etmek için "ilişkisiz ölçümler t testi" kullanılmıştır. Bununla ilgili veriler Tablo 5’te verilmiştir.

Tablo 5. Deney ve kontrol grubu öğrencilerinin son test planlı yazma puanlarına ait ilişkisiz ölçümler t testi sonuçları

\begin{tabular}{|c|c|c|c|c|c|c|c|}
\hline Metin türü & Grup & $\mathbf{N}$ & $\bar{X}$ & $\mathbf{S}$ & Sd & $\mathbf{t}$ & $\mathbf{p}$ \\
\hline \multirow{2}{*}{ 1. Hazırlık } & 1. Deney son test & 82 & 2,60 & 1,009 & \multirow{2}{*}{162} & \multirow{2}{*}{887} & \multirow{2}{*}{ 377 } \\
\hline & 2. Kontrol son test & 82 & 2,46 & ,972 & & & \\
\hline \multirow{2}{*}{ 2. Planlama } & 1. Deney son test & 82 & 2,81 & 1,182 & \multirow{2}{*}{162} & \multirow{2}{*}{3,309} & \multirow{2}{*}{,001 } \\
\hline & 2. Kontrol son test & 82 & 2,25 & ,978 & & & \\
\hline \multirow{2}{*}{ 3. Geliştirme } & 1. Deney son test & 82 & 2,67 & ,904 & \multirow{2}{*}{162} & \multirow{2}{*}{,253 } & \multirow{2}{*}{,800 } \\
\hline & 2. Kontrol son test & 82 & 2,63 & ,945 & & & \\
\hline \multirow{2}{*}{ 4. Düzeltme } & 1. Deney son test & 82 & 3,04 & ,967 & \multirow{2}{*}{162} & \multirow{2}{*}{,- 197} & \multirow{2}{*}{,844 } \\
\hline & 2. Kontrol son test & 82 & 3,07 & 1,135 & & & \\
\hline \multirow{2}{*}{ 5. Sunum } & 1. Deney son test & 82 & 2,78 & 1,224 & \multirow{2}{*}{162} & \multirow{2}{*}{,709 } & \multirow{2}{*}{ 479 } \\
\hline & 2. Kontrol son test & 82 & 2,64 & 1,305 & & & \\
\hline \multirow{2}{*}{$\begin{array}{l}\text { Yazılı Anlatım } \\
\text { Becerileri } \\
\text { Toplam }\end{array}$} & 1. Deney son test & 82 & 2,78 & ,936 & \multirow[b]{2}{*}{162} & \multirow[b]{2}{*}{1,139} & \multirow[b]{2}{*}{ 257 } \\
\hline & 2. Kontrol son test & 82 & 2,61 & ,958 & & & \\
\hline
\end{tabular}

* p<. 0.5 anlamlı

Tablo 5'te deney ve kontrol grubu öğrencilerinin yazılı anlatım becerileri son test puan ortalamaları verilmiştir. 4+1 PYDM'ye dayalı yazma eğitimi etkinlikleri uygulamaları sonrasında deney grubunun son test planlı yazma becerileri ortalaması $(2,78)$, geleneksel yazma eğitimi etkinlikleri yapan kontrol grubuna göre daha $(2,61)$ yüksektir. Deney ve kontrol grubu öğrencilerinin son test yazılı anlatım becerileri arasında anlamlı bir farkın olup olmadığını belirlemek için puan ortalamaları ilişkisiz ölçümler $\mathrm{t}$ testi ile sınanmıştır. Genel olarak deney grubu ile kontrol grubu öğrencilerinin son test planlı yazma puan ortalamaları arasında anlamlı bir farkın olmadığı $\left[\mathrm{t}_{(162)}=1,139, \mathrm{p}>, 257\right]$, fakat yazma sürecinin planlama aşamasına ilişkin deney grubunun lehine $\left[t_{(162)}=3,309, p<, 001\right]$ anlamlı bir farkın olduğu belirlenmiştir. Bu durum, 8 . sınıflarda uygulanan 4+1 PYDM'nin öğrencilerin özellikle yazılı anlatımda planlama becerilerini geliştirdiği şeklinde yorumlanabilir. Bu çalışma verileri ile benzer diğer araştırmaların bulguları (Özkara, 2007; Karatay, 2011; Sever, 2013 ve Şentürk, 2009) genel olarak değerlendirildiğinde 4+1 PYDM'nin, öğrencilerin yazma becerilerini ürün odaklı geleneksel yöntemlere göre daha fazla geliş̧irdiği söylenebilir. 
Üçüncü alt problem: Kontrol grubu öğrencilerinin ön-son test yazılı anlatım becerileri arasında anlamlı bir fark var mıdır?

Bu problemin çözümlenmesinde, kontrol grubu öğrencilerinin ön-son test yazılı anlatım becerileri puan ortalamalarından yararlanılmıştır. Kontrol grubu öğrencilerinin ön-son test yazılı anlatım becerileri arasında anlamlı bir farkın olup olmadığını test etmek için "ilişkili ölçümler $\mathrm{t}$ testi" kullanılmıştır. Bununla ilgili veriler Tablo 6'da verilmiştir.

Tablo 6. Kontrol grubu öğrencilerinin ön-son test planlı yazma becerilerine ait ilişkili ölçümler $t$ testi sonuçları

\begin{tabular}{|c|c|c|c|c|c|c|c|}
\hline Metin türü & Grup & $\mathbf{N}$ & $\bar{X}$ & $\mathbf{S}$ & Sd & $\mathbf{t}$ & $\mathbf{p}$ \\
\hline \multirow{2}{*}{ 1. Hazırlık } & 1. Kontrol ön test & 82 & 2,40 & 1,027 & \multirow{2}{*}{162} & \multirow{2}{*}{,- 390} & \multirow{2}{*}{ 697 } \\
\hline & 2. Kontrol son test & 82 & 2,46 & 972 & & & \\
\hline \multirow{2}{*}{ 2. Planlama } & 1. Kontrol ön test & 82 & 2,25 & 1,054 & \multirow{2}{*}{162} & \multirow{2}{*}{,000 } & \multirow{2}{*}{1,000} \\
\hline & 2. Kontrol son test & 82 & 2,25 & ,978 & & & \\
\hline \multirow{2}{*}{ 3. Geliştirme } & 1. Kontrol ön test & 82 & 2,65 & ,978 & \multirow{2}{*}{162} & \multirow{2}{*}{122} & \multirow{2}{*}{ 903 } \\
\hline & 2. Kontrol son test & 82 & 2,63 & ,945 & & & \\
\hline \multirow{2}{*}{ 4. Düzeltme } & 1. Kontrol ön test & 82 & 2,84 & 1,142 & \multirow{2}{*}{162} & \multirow{2}{*}{$-1,257$} & \multirow{2}{*}{ 211 } \\
\hline & 2. Kontrol son test & 82 & 3,07 & 1,135 & & & \\
\hline \multirow{2}{*}{ 5. Sunum } & 1. Kontrol ön test & 82 & 2,59 & 1,195 & \multirow{2}{*}{162} & \multirow{2}{*}{,- 218} & \multirow{2}{*}{,827 } \\
\hline & 2. Kontrol son test & 82 & 2,64 & 1,305 & & & \\
\hline \multirow{2}{*}{$\begin{array}{l}\text { Yazılı Anlatım } \\
\text { Becerileri } \\
\text { Toplam }\end{array}$} & 1. Kontrol ön test & 82 & 2,55 & 967 & \multirow{2}{*}{162} & \multirow{2}{*}{,- 411} & \multirow{2}{*}{,682 } \\
\hline & 2. Kontrol son test & 82 & 2,61 & ,958 & & & \\
\hline
\end{tabular}

* p<. 0.5 anlamlı

Tablo $6^{\prime}$ da kontrol grubu öğrencilerinin geleneksel yazma eğitimi uygulamaları ile ilgili ön-son test yazılı anlatım becerileri ortalamaları verilmiştir. Geleneksel eğitimle yazma etkinlikleri yapan öğrencilerin yazma becerileri ön test puan ortalamaları $(2,55)$, son test puan ortalamaları ise $(2,61)^{\prime}$ dir. Kontrol grubu öğrencilerinin ön test-son test yazma becerileri arasında anlamlı bir farkın olup olmadığını belirlemek için puan ortalamaları, ilişkili ölçümler ttesti ile sınanmıştır. Kontrol grubu öğrencilerinin ön test-son test planlı yazma becerileri puan ortalamaları arasında anlamlı bir farkın olmadığı $\left[\mathrm{t}_{(162)}=-, 411, \mathrm{p}>, 682\right]$ belirlenmiştir. Bu durum, okullarda geleneksel anlayışla yürütülen yazma eğitimi etkinliklerinin 8. sınıf öğrencilerinin planlı yazma becerilerini geliştirmediğini göstermektedir. Planlı yazma sürecinin hazırlık, planlama, geliştirme, düzeltme ve sunum olmak üzere bütün aşamalarında gelişmenin olmaması, öğretmenlerin yazma becerisinin geliştirilmesine yönelik program kazanımlarını izlemediği ve/veya Türkçe dersi öğretim araçlarının bu konuda yeterli olmadığı şeklinde de yorumlanabilir. Bu bulgu daha önce sürece dayalı yazılı anlatım becerisini geliştirmeye yönelik farklı seviyelerde 
yapılan çalışmalarla da benzerlik göstermektedir (Özkara, 2007; Şentürk, 2009; Uzun ve Ülper, 2009; Karatay, 2011b; Sever, 2013; Özdemir, 2014; Kaldırım, 2014). Sürece dayalı yazma etkinliklerinin, ürün odaklı yazma etkinliklerine göre yazılı anlatım becerilerini daha iyi geliştirdiğini bu veriler de göstermektedir. Fakat yazma sürecinde öğrencilere yazma ürünleri ile ilgili sürekli dönüt vermek öğretmenlerden daha çok çaba ister, ayrıca Türkçe ders araçlarında bununla ilgili nitelikli yazma etkinliklerinin olması da yazma becerilerinin gelişiminde önemlidir.

Dördüncü alt problem: Deney grubu öğrencilerinin ön-son test yazılı anlatım tutumları arasında anlamlı bir fark var mıdır?

Bu problemin çözümlenmesinde, deney grubu öğrencilerinin ön-son test yazılı anlatım tutumu ölçeğine verdikleri puanların ortalamalarından yararlanılmıştır. Deney grubu öğrencilerinin ön-son test yazılı anlatım tutum puanları arasında anlamlı bir farkın olup olmadığını test etmek için “ilişkili ölçümler t testi” kullanılmıştır. Bununla ilgili veriler Tablo 7’de verilmiştir.

Tablo 7. Deney grubunun ön-son test yazılı anlatım tutumlarına ait ilişkili ölçümler $t$ testi

\begin{tabular}{ccccccc}
\multicolumn{1}{c}{ sonuçları } & $\mathbf{N}$ & $\overline{\mathrm{X}}$ & $\mathbf{S}$ & $\mathbf{S d}$ & $\mathbf{T}$ & $\mathbf{P}$ \\
\hline Grup & $\mathbf{N}$ & & & & \\
1. Deney ön test & 82 & 3,60 &, 611 & 162 &,- 388 &, 669 \\
2. Deney son test & 82 & 3,63 &, 615 & & &
\end{tabular}

$* p<0.5$ anlamlı

Tablo 7'de deney grubu öğrencilerinin yazılı anlatıma ilişkin ön-son test tutum puan ortalamaları yer almaktadır. Deney grubu öğrencilerinin ön test yazılı anlatım tutumu puan ortalamaları $(3,60)$, son test puan ortalamaları ise $(3,63)^{\prime}$ tür. Deney grubu öğrencilerinin ön-son test puanları arasında anlamlı bir farkın olmadığı $\left[\mathrm{t}_{(162)}=-, 388, p>, 669\right]$ belirlenmiştir. Bu durum, 8. sınıf öğrencilerinin yazılı anlatıma karşı tutumlarının 4+1 PYDM uygulamaları öncesinde de iyi düzeyde olması ile açıklanabilir. Bu konudaki diğer araştırmalar incelendiğinde öğrencilerin yazmaya ilişkin tutumlarının olumlu yönde geliştiği görülmektedir (Karatay, 2011b). Mevcut araştırmada öğrencilerin uygulama başlangıcında ve sonunda tutumları arasında olumlu ya da olumsuz bir değişikliğin olmamasının, öğrencilerin başlangıçta yazmaya karşı olumlu tutuma sahip olmaları, bu konuda belli bir doyuma sahip olmaları ile açıklanabilir.

Beşinci alt problem: Kontrol grubu öğrencilerinin ön-son test yazıı anlatım tutumları arasında anlamlı bir fark var mıdır?

Bu problemin çözümlenmesinde, kontrol grubu öğrencilerinin ön-son test yazılı anlatım tutumu ölçeğine verdikleri puanların ortalamalarından yararlanılmıştır. Kontrol grubu 
öğrencilerinin ön-son test yazılı anlatım tutum puanları arasında anlamlı bir farkın olup olmadığını test etmek için “ilişkili ölçümler t testi” kullanılmıştır. Bununla ilgili veriler Tablo 8’ de verilmiştir.

Tablo 8. Kontrol grubunun ön-son test yazılı anlatım tutumlarına ait ilişkili ölçümler testi

\begin{tabular}{|c|c|c|c|c|c|c|}
\hline Grup & $\mathbf{N}$ & $\bar{X}$ & $\mathbf{s}$ & $S d$ & $\mathbf{t}$ & $\mathbf{P}$ \\
\hline 1. Kontrol ön test & 82 & 3,59 & ,496 & 162 & ,877 - - & 382 \\
\hline 2. Kontrol son test & 82 & 3,51 & ,592 & & & \\
\hline
\end{tabular}

$* p<0.5$ anlamlı

Tablo 8'de kontrol grubu öğrencilerinin ön-son test yazılı anlatım tutum puanı ortalamaları yer almaktadır. Kontrol grubu öğrencilerinin ön test yazııı anlatım tutum puanı ortalamaları $(3,59)$, son test puan ortalamaları ise $(3,51)$ 'dir. Kontrol grubu öğrencilerinin geleneksel yazma eğitimi uygulamaları yazılı anlatıma karşı tutum ön-son test puanları arasında anlamlı bir fark [ $\left.\mathrm{t}_{(162)}=, 877, \mathrm{p}>, 382\right]$ yaratmamıştır. Bu durum, 8. sınıf öğrencilerinin başlangıçta yazılı anlatıma karşı tutumlarının iyi olması ve öğretim sürecinde öğretmenin geleneksel öğretim etkinliklerinin de tutumlarında fazla değişiklik yapmaması ile açıklanabilir. Bu bulgu, benzer araştırma bulguları ile de tutarlıdır (Karatay, 2011b; Özdemir, 2014). Fakat bu öğrenci grubunun yazmaya karşı genel olarak iyi bir tutuma sahip olması, geleneksel yazma etkinliklerinin öğrencilerin yazmaya yönelik tutumlarını olumlu ya da olumsuz yönde değiştirmediği anlamına gelebilir.

Altıncı alt problem: Deney ve kontrol grubu öğrencilerinin son test yazılı anlatım tutumları arasında anlamlı bir fark var mıdır?

Bu problemin çözümlenmesinde, deney ve kontrol grubu öğrencilerinin son test yazılı anlatım tutum ölçeğine verdikleri puanların ortalamalarından yararlanılmıştır. Deney ve kontrol grubu öğrencilerinin son test yazılı anlatım tutum puanları arasında anlamlı bir farkın olup olmadığını test etmek için "ilişkisiz ölçümler t testi” kullanılmıştır. Bununla ilgili veriler Tablo 9'da verilmiştir.

Tablo 9. Deney ve kontrol grubunun son test yazılı anlatım tutumlarına ait ilişkisiz ölçümler t testi

\begin{tabular}{|c|c|c|c|c|c|c|}
\hline Grup & $\mathbf{N}$ & $\bar{X}$ & $\mathbf{S}$ & Sd & $T$ & $\mathbf{P}$ \\
\hline 1. Deney son test & 82 & 3,63 & 615 & 162 & 1,274 & 205 \\
\hline 2. Kontrol son test & 82 & 3,51 & ,592 & & & \\
\hline
\end{tabular}


$* p<0.5$ anlamlı

Tablo 9'da deney ve kontrol grubu öğrencilerinin yazııı anlatım tutumlarına ilişkin son test puan ortalamaları yer almaktadır. Deney grubu öğrencilerinin yazılı anlatım tutumları son test puan ortalamaları $(3,63)$, kontrol grubunun son test puan ortalamaları $(3,51)^{\prime}$ dir. Deney ve kontrol grubu öğrencilerinin yazılı anlatıma karşı son test tutum puanları arasında anlamlı bir farkın olmadığı $\left[t_{(162)}=1,274, p>, 205\right]$ belirlenmiştir. Bu durum, uygulama öncesinden her iki grubun da yazılı anlatıma karşı olumlu ve iyi düzeyde bir tutuma sahip olmaları ile açıklanabilir. Farklı seviyelerde yapılan araştırmalar incelendiğinde öğrencilerin yazılı anlatım tutumlarında deney grubu lehine değişiklikler olduğu bilinmektedir (Karatay, 2011b; Özdemir, 2014). Ancak bu araştırmada bir değişmenin görülmemesinin, her iki grupta bulunan öğrencilerin uygulama öncesinde yazmaya karşı tutumlarının iyi ve olumlu düzeyde olmasından kaynaklandığı söylenebilir. Bu durumu açıklamak, 4+1 PYDM'nin öğrencilerin yazılı anlatım becerileri ve tutumları üzerindeki etkisini belirlemek için deney grubu öğrencileriyle yapılan görüşme verilerinden yararlanılmıştır.

Yedinci alt problem: Deney grubu öğrencilerinin 4+1 PYDM ile ilgili görüşleri nedir?

Bu problemin çözümlenmesinde, deney grubu öğrencileri ile 4+1 PYDM yazma etkinlikleri hakkında yapılan görüşmenin içerik analizinden yararlanılmıştır. Bunun için deney grubu öğrencilerine "Planlı Yazma ve Değerlendirme çalışmalarının kendileri için faydalı olup olmadığı" sorulmuş, kendilerinden yazılı olarak alınan görüşlerin analizi sonucunda şu bulgulara ulaşılmıştır.

Tablo 10. Deney grubunun "planlı yazma ve değerlendirme çalışmalarının kendileri için faydalı olup olmadığı"na ilişkin görüşleri

Görüşme sorusu: Planlı Yazma ve Değerlendirme çalışmaları sizin için faydalı oldu mu?

Faydalı oldu

Faydalı olmadı

Kararsızım

Tablo $10^{\prime}$ da görüldüŭg̈ü gibi öğrencilerin $63(\% 76,8)^{\prime}$ ü çalışmanın kendileri için faydalı olduğunu, 10 (\%12,1)'u faydalı olmadığını ve $9(\% 10,9)^{\prime}$ u bu konuda kararsı olduğunu düşünmektedir. Faydalı olduğunu düşünen öğrenciler, yazma sürecinin aşamaları hakkında 
edindikleri kazanımları belirtmişlerdir. Bu uygulamayı yararlı bulan öğrencilerin çoğunluğu "yazmaya başlamadan önce araştırma yapılması gerektiği, ana fikri önceden belirlemenin önemli olduğu ve ana fikirsiz yazı olamayacağı, başlığın en son yazılması gerektiği, giriş-geliş̧me ve sonuç bölümlerinde nelerin olması gerektiği ile yazdıktan sonra yazıyı gözden geçirmenin önemli olduğu hakkında bilgi sahibi olduklarını" bildirmişlerdir. Genel olarak öğrenciler (\%76,8'i), 4+1 PYDM'yi kendileri için yararlı bulduklarını ifade etmiş, $\% 12,1^{\prime} i$ çalışmayı kendileri için faydalı bulmadıklarını ifade etmiştir. Ancak neden faydalı bulmadıklarına dair görüş bildirmemişlerdir. Deney grubu öğrencilerinin \%10,9'unun ifadesinden ise olumlu ya da olumsuz bir sonuç çıkarılamamıştır. Öğrenciler, yazma becerisinin bir üst eğitim kurumuna geçişte düşünme sürecini bilinçli ve etkili kullanmanın farkında olmadıkları, ayrıca üst eğitim kurumlarına geçişte girilen sınavlarda bu becerinin de ölçülememesi ve değerlendirmeye alınmaması öğrencilerin önemi hakkında yeteri kadar bilinç edinememelerine neden olduğu söylenebilir.

\section{Sonuç ve Tartışma}

Deney grubu öğrencilerinin ön-son test 4+1 Planlı Yazma ve Değerlendirme Modeli'ne dayalı planlı yazma puan ortalamaları arasında anlamlı bir farkın olduğu belirlenmiştir. Bu durum, 8. sınıf öğrencilerinin planlı yazma düzeylerini artırmaya yönelik 4+1 PYDM'ye dayalı uygulanan yazma eğitimi etkinliklerinin öğrencilerin planlı yazma sürecine ilişkin hazırlık, planlama, geliştirme, düzeltme ve sunum aşamalarının tamamını anlamlı fark yaratacak düzeyde geliştirdiğini göstermektedir. Bu bulgu, farklı tarihlerde ve öğretim düzeylerinde sürece dayalı yazma ile ilgili yapılan araştırma bulguları Karatay (2011b), Özkara (2007), Şentürk (2009) ve Sever (2013) ile tutarlıdır. Yazma eğitiminde ürün odaklı eğitim yerine süreci işletmeyi öğrenmek öğrencilerin yazma becerilerine daha çok katkı sağlamaktadır. Temel eğitimde uygulanan Türkçe Dersi Öğretim Programlarında sürece dayalı planlı yazma ve değerlendirme becerisini geliştirmeye yönelik öğretim teknikleri ve etkinliklerinin önerilmemesi, öğretmenlerin ürün odaklı geleneksel yazma anlayışını sürdürmelerine neden olmakta, bu durum öğrencilerin yazma bilinci ve nitelikli yazma becerisi edinmemelerine neden olmaktadır.

Deney ve kontrol grubu öğrencilerinin son test planlı yazma puan ortalamaları arasında anlamlı bir farkın olmadığı, fakat yazma sürecinin planlama aşamasına ilişkin deney grubunun lehine anlamlı bir farkın olduğu belirlenmiştir. Bu durum, 8. sınıflarda uygulanan 4+1 PYDM'nin öğrencilerin özellikle yazılı anlatımda planlama becerilerini geliştirdiğini göstermektedir. Bu, düşündüklerini etkili sunabilme açısından önemlidir. Bu bulgu, Şentürk (2009) ile Karatay (2011b)'ın farklı örneklemler üzerinde yaptıkları uygulamalar sonucunda elde ettikleri bulguları desteklemektedir. Planlama, yazmaya başlamadan önce yazılacakların düzenlenmesi, eksiklerin 
tamamlanması, mantık sırasının oluşturulması, fikirlerin yazının uygun bölümlerine dağıtılması gibi birçok zihinsel süreci kapsar. Süreç temelli benzer yaklaşımlar incelendiğinde 4+1 PYDM'nin diğer modellere göre bu aşamayı daha çok öncelediği görülür, çünkü duygu ve düşünceleri etkili anlatma, yazarken zaman kaybına uğramayı önlemenin temel aşamalarından birini oluşturmaktadır.

Kontrol grubu öğrencilerinin ön-son test planlı yazma becerileri puan ortalamaları değerlendirildiğinde anlamlı bir farkın olmadığı belirlenmiştir. Bu durum, okullarda ürün odaklı geleneksel anlayışla yürütülen yazma eğitimi etkinliklerinin 8. sınıf öğrencilerinin planlı yazma becerilerine katkı sağlamadığını göstermektedir. Planlı yazma sürecinin hazırlık, planlama, geliştirme, düzeltme ve sunum aşamalarının tamamında gelişmenin olmaması, öğretmenlerin öğrencilerin yazma becerilerini geliştirmeye yönelik Türkçe Dersi Öğretim Programındaki kazanımları dikkate alarak yazılı anlatım etkinlileri yapmadıkları ve/veya Türkçe dersi öğretim araçlarının bu konuda yeterli olmadığını düşündürmektedir. Bu bulgu, daha önce yapılan sürece dayalı yazma eğitimi ile ilgili araştırma bulgularını desteklemektedir (Kaldırım, 2014; Karatay, 2011b; Özdemir, 2014; Özkara, 2007; Sever, 2013; Şentürk, 2009; Uzun ve Ülper, 2009). Yazma eğitimi için okullarda ürün odaklı yazma eğitimi anlayışı yerine yazma süreci hakkında öğrencilerin bilinçlenmesini sağlayan bir modelin benimsenmesi ve uygulanması gereklidir.

Deney ve kontrol grubu öğrencilerinin yazılı anlatım tutumları değerlendirildiğinde deney grubu öğrencilerinin ön-son test puanları arasında anlamlı bir farkın olmadığı belirlenmiştir. Bu durum, uygulama okulundaki 8. sınıf öğrencilerinin yazılı anlatıma karşı tutumlarının 4+1 PYDM uygulamaları öncesinde de iyi olması ile açıklanabilir. Karatay (2011b) ve Özdemir (2014)'in farklı seviyelerdeki öğrenci grupları ile yaptığı sürece dayalı yazma eğitimi çalışmaları incelendiğinde öğrencilerin yazmaya ilişkin tutumlarının olumlu yönde geliştiği görülmektedir. Bu araştırmada öğrencilerin uygulama başlangıcında ve sonunda tutumları arasında olumlu ya da olumsuz bir değişikliğin olmaması öğrencilerin başlangıçta yazmaya karşı olumlu tutuma sahip olması ile açıklanabilir. Bu durum, deney ve kontrol grubu öğrencilerinin yazılı anlatıma karşı son test tutum puanlarına da yansımıştır.

Deney grubu öğrencileri ile 4+1 PYDM hakkında yapılan görüşmeden elde edilen bulgulara göre öğrencilerin 63 (\%76,8)'ü çalışmanın kendileri için faydalı olduğunu, 10 (\%12,1)'u faydalı olmadığını ve $9(\% 10,9)^{\prime}$ u bu konuda kararsız olduğunu düşünmektedir. Faydalı olduğunu düşünen öğrenciler, yazma sürecinin aşamaları hakkında edindikleri kazanımları belirtmişlerdir. Bu uygulamayı yararlı bulan öğrencilerin çoğunluğu "yazmaya başlamadan önce araştırma yapılması gerektiği, ana fikri önceden belirlemenin önemli olduğu ve ana fikirsiz yazı 
olamayacağı, başlığın en son yazılması gerektiği, giriş-gelişme ve sonuç bölümlerinde nelerin olması gerektiği ile yazdıktan sonra yazıyı gözden geçirmenin önemli olduğu hakkında bilgi sahibi olduklarını" bildirmişlerdir. Genel olarak öğrenciler, 4+1 PYDM'yi $\left(\% 76,8^{\prime} i\right)$ kendileri için yararlı bulduklarını ifade etmiş, \%12,1'i çalışmayı kendileri için faydalı bulmadıklarını ifade etmiş; ancak neden faydalı bulmadıklarına dair görüş bildirmemişlerdir. Deney grubu öğrencilerinin \%10,9'unun ifadesinden ise olumlu ya da olumsuz bir sonuç çıkarılamamıştır. Öğrenciler, yazma becerisinin bir üst eğitim kurumuna geçişte düşünme sürecini bilinçli ve etkili kullanmanın farkında olmadıkları, ayrıca üst eğitim kurumlarına geçişte girilen sınavlarda bu becerinin de ölçülememesi ve değerlendirmeye alınmaması öğrencilerin önemi hakkında yeteri kadar bilinç edinememelerine neden olduğu söylenebilir.

Genel olarak araştırmada deney grubunda bulunan öğrencilere uygulanan 4+1 PYDM etkinliklerinin yazılı anlatım becerilerini geliştirdiği görülmüştür. Araştırmanın uygulama süresinin bir eğitim-öğretim dönemi olduğu düşünüldüğünde öğrencilerde dikkate değer bir gelişim gözlemlenmiştir. Kontrol grubunda ise yazılı anlatım becerisine ilişkin bir gelişimin olmadığı görülmüştür. Bu durum mevcut Türkçe Dersi Öğretim Programlarının ve Türkçe dersi öğretim araçlarının ve/veya öğretmenlerin izledikleri öğretim anlayışının yazılı anlatım becerisini geliştirme bakımından yeterli olmadığı sonucunu ortaya koymaktadır. Yıllardır okullarda benimsenen ürün odaklı yazma eğitimi anlayışının sürece dayalı yazma eğitimi anlayışına dönüşmesi gerekir. Çünkü etkili bir yazılı anlatım becerisi edinmek için yazma süreci hakkında bilinçli olmak ve yeteri kadar deneyimler kazanmak, nitelikli uygulama etkinlikleri ile mümkündür. Ayrıca yazma becerisi de bir üst eğitim kurumlarına geçmede bir değerlendirme aracı olarak kullanılmadıkça dört başı mamur dil eğitiminden söz edilemez. Bu yüzden öğretim programları ve öğretim araçları tekrar gözden geçirilerek dil becerilerini bütüncül olarak geliştirecek niteliğe kavuşturulabilir.

\section{Kaynaklar}

Akyol, H. (2012). Programa uygun Türkçe öğretim yöntemleri. Ankara: Pegem Akademi Yayınları. Beyreli, L., Çetindağ, Z. \& Celepoğlu, A. (2011). Yazııı ve sözlü anlatım. Ankara: Pegem Akademi Yayınları. Coşkun, E. (2007). Yazma eğitimi. A. KIRKKILIÇ, H. AKYOL (Eds.) ilköğretimde Türkçe öğretimi, (ss. 1-13). Ankara: Pegem Akademi Yayınları.

Culham, R. (2010). Traits of writing. The complete qide for middle school. New York: Scholastic.

Emir, S. (1986). Üniversitelerdeki Türkçe dersleri için Yök tavsiyeli kompozisyon yazma sanatı. İstanbul: Türk Dünyası Araştırmaları Vakfı Yayınları. 
Flower, L.S. ve Hayes, J.R. (1977). Problem-solving strategies and the writing process. College English, 39 (4), 449-461.

Johnson, A. (2008). Teaching reading and writing. Plymouth: Rowman \& Littlefield Publishers.

Kaldırım, A. (2014). 6+1 Analitik yazma ve değerlendirme modeli'nin ortaokul altıncı sınıf öğrencilerinin yazılı anlatım becerilerine etkisi. Kütahya: Dumlupınar Üniversitesi, Yayımlanmamış Yüksek Lisans Tezi.

Karatay, H. (2011a). Süreç temelli yazma modelleri: 4+1 planlı yazma ve değerlendirme. M. Özbay (Ed.), Yazma eğitimi (1.Baskı), (ss. 20-43). Ankara: Pegem Akademi.

Karatay, H. (2011b). 4+1 planlı yazma ve değerlendirme modelinin öğretmen adaylarııın yazılı anlatım tutumlarını ve yazma becerilerini geliştirmeye etkisi. Turkish Studies-International Periodical For The Languages, Literature and History of Turkish or Turkic, 6 (3), 1029-1047.

Karatay, H. (2013). Süreç temelli yazma modelleri: 4+1 planlı yazma ve değerlendirme. M. Özbay (Ed.), Yazma eğitimi (3.Baskı), (ss. 21-48). Ankara: Pegem Akademi.

Millî Eğitim Bakanlığı (2006). ilköğretim Türkçe dersi öğretim programı ve kılavuzu (6, 7, 8. Sınıflar). Ankara: Devlet Kitapları Müdürlüğü.

Millî Eğitim Bakanlığı (2012). Ortaokul ve Imam Hatip Ortaokulu yazarlık ve yazma becerileri dersi (5, 6, 7 ve 8. sınıflar) öğretim programı. Ankara: Milli Eğitim Bakanlı̆̆ı Yayınları.

Özbay, M. (2000). Ilköğretim okulu öğrencilerinin yazııı anlatım becerileri. Ankara: Bizim Büro Basım Evi.

Özdemir, B. (2014). Analitik yazma ve değerlendirme modelinin Türkçe öğretmeni adaylarının yazma becerisine ve yazma tutumlarına etkisi. Ankara: Gazi Üniversitesi, Yayımlanmamış Doktora Tezi.

Özkara, Y. (2007). 6+1 Analitik yazma ve değerlendirme modelinin 5. Sınıf öğrencilerinin hikâye edici metin yazma becerilerini geliştirmeye etkisi. Ankara: Gazi Üniversitesi, Yayımlanmamış Doktora Tezi.

Pilav, S. ve Ünalan, Ş. (2012). Eğitim fakülteleri için yazılı ve sözlü anlatım. Ankara: Nobel Akademik Yayıncilık.

Sever, E. (2013). Süreç temelli yazma modellerinin ilkokul 4'üncü sınıf öğrencilerinin yazılı anlatım ve yaratıcı yazma becerilerine etkisi. Zonguldak: Bülent Ecevit Üniversitesi, Yayınlanmamış Yüksek Lisans Tezi.

Şentürk, N. (2009). Planlı yazma ve değerlendirme modelinin 8. sınıf öğrencilerinin bilgilendirici metin yazma becerilerini geliştirmeye etkisi. Bolu: Abant İzzet Baysal Üniversitesi, Yayınlanmamış Yüksek Lisans Tezi.

Tompkins, G. (2005). Language arts: Patterns of practice. New Jersey: Pearson Merrill Prentice Hall Publication.

Tompkins, G. (2008). Teaching writing: Balancing process and product. New Jersey: Pearson Merrill Prentice Hall Publication.

Uzun, L. \& Ülper, H. (2009). Bilişsel süreç modeline göre hazırlanan yazma öğretimi izlencesinin öğrenci başarııına etkisi. Illköğretim Online (Elementary Education Online), (8), 3, 651-665.

Yalçın, A. (2002). Türkçe öğretim yöntemleri yeni yaklaşımlar. Ankara: Akçağ Yayınları. 